\title{
Predictors of COVID-19 among Healthcare Workers who were Exposed to COVID-19
}

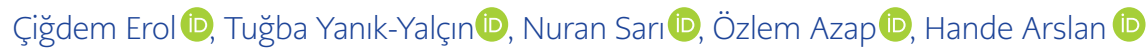 \\ Department of Infectious Diseases and Clinical Microbiology, Başkent University School of Medicine, Ankara, Turkey
}

\begin{abstract}
Background: We described the outcomes of healthcare workers (HCWs) who have been exposed to COVID-19.

Materials and Methods: We included the HCWs exposed COVID-19 and admitted to the COVID-19 outpatient clinic between March 13 and August 31, 2020, at a university hospital in Ankara, Turkey. The clinical data and exposure status were retrospectively obtained from medical records.

Results: We analyzed 809 admissions of 690 HCWs. In total, 490 HCWs were admitted after suspected exposure to COVID-19 patients. In 32\% of these admissions, typical symptoms were observed, and 15\% of them developed COVID-19. Polymerase chain reaction test for SARS-CoV-2 was positive in \%10 of asymptomatic HCWs. Exposure outside the hospital was 2.3 times more common (OR 2.28, $\mathrm{p}=0.020$, CI 1.141-4.543) than exposure in the hospital. In the hospital setting, exposure to a patient was 1.6 times higher than social contact with colleagues during work. Male gender and occupations other than doctors were independent risk factors. Among HCWs diagnosed with COVID-19, 13\% required hospitalization; fortunately, there were no intensive care unit admissions and no deaths.

Conclusion: After suspected exposure, HCWs should be screened for SARS-CoV-2 and monitored closely for symptom development. Strict infection control precautions and appropriate personal protective equipment use are crucial to reducing transmission of SARS-CoV-2 both in the hospital setting and in social life.

Keywords: Healthcare worker (HCW), COVID-19, SARS-CoV-2, exposure, asymptomatic infection
\end{abstract}

\section{INTRODUCTION}

S ARS-CoV-2 is transmitted via the inhalation of infected droplets or through direct contact with contaminated surfaces. Aerosol-generating procedures can also lead to airborne transmission (1). Healthcare workers (HCWs) are at higher risks for infections than the general population because of their close contact with patients or infectious materials (2). According to the World Health Organization (WHO), approximately 14\% of COVID-19 cases worldwide were reported among healthcare workers, as high as 35\% in some countries (3). The rapid increase in the number of COVID-19
Corresponding Author: Çiğdem Erol

E-mail: ccatalyurekli@yahoo.com

Received: August 08, 2021 Accepted: August 26, 2021 Published: August 31, 2021

Suggested citation: Erol Ç, Yanık-Yalçın T, Sarı N, Azap Ö, Arslan A. Predictors of COVID-19 among healthcare workers who were exposed to COVID-19. Infect Dis Clin Microbiol 2021; 2: 87-96.

DOI: 10.36519/idcm.2021.74 
cases may result in more healthcare professionals becoming infected. Furthermore, the more healthcare professionals get infected, the more the health system is disrupted, and the effects of the pandemic become more severe (4). Previous studies on the COVID-19 exposure status of HCWs in Turkey are limited. Therefore, we aimed to evaluate the clinical characteristics of admissions in HCWs for COVID-19 and the exposure status of those admissions.

\section{MATERIALS AND METHODS}

This retrospective study enrolled HCWs admitted to the COVID-19 outpatient clinic due to COVID-19 symptoms or exposed to COVID-19 patients between March 13 and August 31, 2020, at a university hospital in Ankara, Turkey. The occupational, clinical, laboratory and radiologic data were retrospectively obtained from their medical records. The Strengthening the Reporting of Observational Studies in Epidemiology (STROBE) checklist was used for the study design.

The WHO's definitions for probable and confirmed cases were used in the diagnosis of COVID-19. A probable case is a suspected case with radiological findings suggestive of COVID-19, whereas a confirmed case is a person with laboratory confirmation of COVID-19, irrespective of clinical signs and symptoms [(5)]. Typical COVID-19 symptoms were recorded according to the Centers for Disease Control and Prevention criteria (6).

Combined nasopharyngeal and oropharyngeal swabs were obtained from symptomatic HCWs at the time of admission and from asymptomatic HCWs five or seven days after their exposure to a COVID-19 patient if their contact status were high/or medium. Exposure risk assessment was made according to the Republic of Turkey Ministry of Health COVID-19 Guide (7). Assessment of healthcare professionals' contact status with COVID-19 patients is shown in Table 1. Laboratory confirmation was made based on a positive polymerase chain reaction (PCR) test.

SARS-CoV-2 RNA was extracted using the viral nucleic acid extraction buffer (vNAT®, Bioeksen R\&D
Technologies Inc., Turkey), and reverse transcriptionPCR was performed using the Bio-Speedy ${ }^{\circledR}$ Direct RT-qPCR SARS-CoV-2 nucleic acid detection kit (Bioeksen R\&D Technologies Inc., Turkey).

All data were analyzed using the IBM SPSS Statistics for Windows, Version 25.0. (Armonk, NY: IBM Corp.). The chi-square test was used to analyze categorical variables. Continuous numerical variables were not normally distributed and thus are presented as median values and were compared using the Mann-Whitney $U$ test. Multivariate analysis was performed to assess the risk of infection. Logistic regression was performed by including all the variables; a p-value $<0.05$ was considered statistically significant.

\section{RESULTS}

Overall, 809 admissions of 690 HCWs were analyzed in this study. The female to male ratio was 1.7:1. The median age was 33 years (interquartile range [IQR] 26-42 years). Among the HCWs, 25\% were doctors, and $23 \%$ were nurses. The distribution of occupations is shown in Figure 1. In total, 476 HCWs (59\%) had typical COVID-19 symptoms during admission, of whom 119 (25\%) were diagnosed with COVID-19. There were 113 confirmed cases and six probable cases (Figure 2). Among infected HCWs, $24 \%(n=28)$ worked in departments where COVID 19 patients are primarily followed as emergency room, intensive care unit, inpatient and outpatient COVID-19 departments. A control PCR test was

\section{HIGHLIGHTS}

- Healthcare workers (HCWs) are at higher risk of coronavirus disease (COVID-19) because of their increased exposure to COVID-19 patients.

- After suspected exposure, HCWs should be screened for SARS-CoV-2 and monitored closely for symptom development to control the transmission of COVID-19 among HCWs.

- Strict infection control protocols and appropriate personal protective equipment use are crucial both inside the hospital and in social or household settings. 
performed in 103 patients, and the median time for negative PCR test results was ten days (IQR 7-14 days). Characteristic radiological features on chest computed tomography were found in 33\% of the COVID-19 cases and 29\% confirmed cases. Among HCWs diagnosed with COVID-19, 13\% required hospitalization. There was no intensive care unit (ICU) admissions and no deaths.

During the study period, $64 \%(n=443)$ of all HCWs at our hospital were exposed to a COVID-19 patient at least once. Although exposure history was significantly more common among doctors (78\%; $\mathrm{P}=0.001)$ than other HCWs, SARS-CoV-2 positivity was detected only in nine doctors (7\%) after a suspected exposure. There were no statistically significant differences among nurses, health technicians, caregivers, or other HCWs ( $\mathrm{p}=0.718$, $0.946,0.212$ and 0.286 , respectively).

There were 490 admissions owing to a suspected exposure either inside (the high- and medium-risk groups) or outside (close contact) the hospital. In $32 \%$ of admissions, typical COVID-19 symptoms were observed, and 15\% developed COVID-19 after exposure. The exposure rates were $90 \%$ and $10 \%$

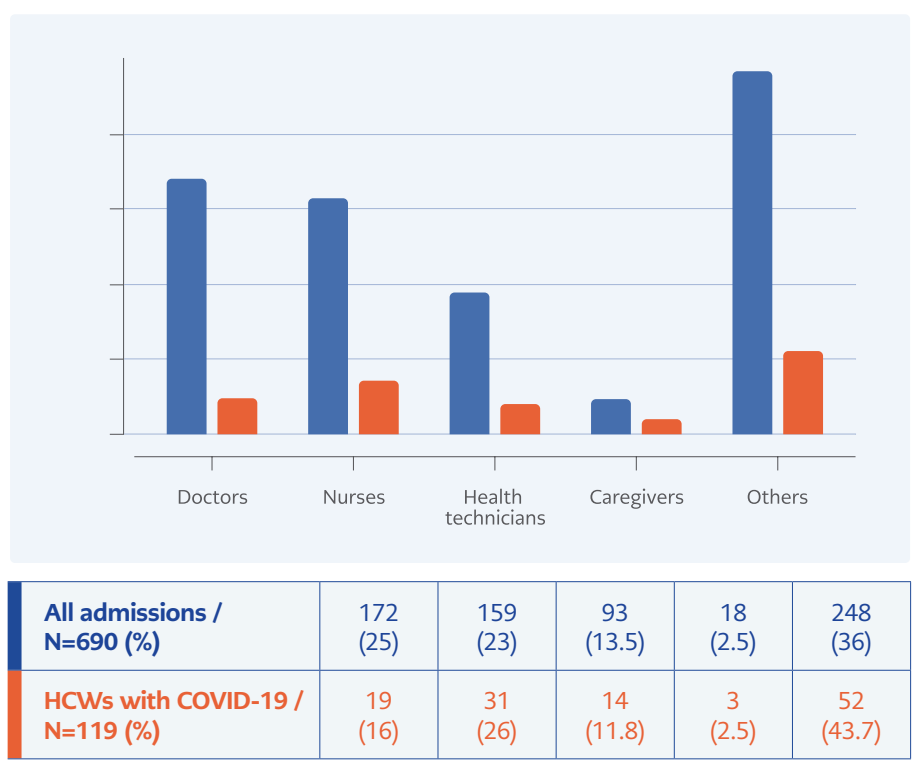

Figure 1. Distribution of occupations.

inside and outside the hospital, respectively. The risk of COVID-19 development after suspected exposure outside the hospital (family member or social contact) was 2.3 times higher (27\%) than that after exposure inside the hospital (14\%), and the difference was statistically significant ( $\mathrm{P}=0.020 \quad 95 \%$ confidence

Table 1. Assessment of healthcare professional's contact status with COVID-19 patient*.

\begin{tabular}{|c|c|c|}
\hline & $\begin{array}{l}\text { Healthcare Professional's Use of } \\
\text { Personal Protective Equipment (PPE) }\end{array}$ & Contact risk \\
\hline \multirow{5}{*}{$\begin{array}{l}\text { Intense contact with the } \\
\text { COVID-19 patient wearing } \\
\text { a medical mask }\end{array}$} & No PPE Used & Medium \\
\hline & $\begin{array}{l}\text { Did not use a medical mask or N95 or use a medical } \\
\text { mask in case of an N95 indication }\end{array}$ & Medium \\
\hline & No eye protection & Low \\
\hline & No gloves or appropriately used & Low \\
\hline & PPE is used appropriately & Not considered risky \\
\hline \multirow{6}{*}{$\begin{array}{l}\text { Intense contact with the } \\
\text { COVID-19 patient not wearing a } \\
\text { medical mask }\end{array}$} & No PPE used & High \\
\hline & No medical mask or N95 used & High \\
\hline & Use of a medical mask in case of $\mathrm{N} 95$ indication & Medium \\
\hline & No eye protection & Medium \\
\hline & No gloves or appropriately used & Low \\
\hline & PPE is used appropriately & Not considered risky \\
\hline
\end{tabular}

${ }^{*}$ Republic of Turkey Ministry of Health, Directorate General of Public Health. COVID-19 Guide (Study of Scientific Board). 
Table 2. Risk factors for COVID-19 development.

\begin{tabular}{|c|c|c|c|c|c|c|c|c|}
\hline & \multirow{2}{*}{$\begin{array}{c}\text { COVID-19 } \\
\text { HCWs }^{*}(n=119) \\
(17 \%)\end{array}$} & \multirow{2}{*}{$\begin{array}{c}\text { Non-infected } \\
\text { HCWs }^{*}(n=572) \\
(83 \%)\end{array}$} & \multicolumn{3}{|c|}{ Univariate analysis } & \multicolumn{3}{|c|}{ Multivariate analysis } \\
\hline & & & $P$ value & $\mathrm{OR}^{\star \star}$ & $95 \% \mathrm{Cl}^{\star \star \star}$ & P value & $\mathrm{OR}^{\star \star}$ & $95 \% \mathrm{Cl}^{\star \star \star}$ \\
\hline Age (median) & $34(20-66)$ & $32(20-80)$ & 0.578 & 1.01 & $0.987-1.024$ & & & \\
\hline Gender & & & 0.012 & 1.66 & $1.18-2.576$ & 0.008 & 1.72 & $\begin{array}{l}1.149- \\
2.576\end{array}$ \\
\hline Female & $63(15 \%)$ & $369(85 \%)$ & & & & & & \\
\hline Male & $56(22 \%)$ & 203 (78\%) & & & & & & \\
\hline $\begin{array}{l}\text { Duration of work } \\
\text { (median) }\end{array}$ & $6(1-32)$ & $5(1-33)$ & 0.205 & 1.02 & $0.991-1.044$ & & & \\
\hline $\begin{array}{l}\text { Experience (Duration } \\
\text { of work }>10 \text { years) }\end{array}$ & $63(20 \%)$ & $56(15 \%)$ & 0.20 & 1.29 & 0.873-1.899 & & & \\
\hline \multicolumn{9}{|l|}{ Occupation } \\
\hline $\begin{array}{c}\text { Doctor } \\
\text { Yes } \\
\text { No }\end{array}$ & $\begin{array}{c}19(11 \%) \\
100(19 \%)\end{array}$ & $\begin{array}{l}153(89 \%) \\
418(81 \%)\end{array}$ & 0.014 & 0.52 & $0.307-0.877$ & 0.006 & 0.47 & $\begin{array}{l}0.277- \\
0.804\end{array}$ \\
\hline $\begin{array}{l}\text { Nurse } \\
\text { Yes } \\
\text { No }\end{array}$ & $\begin{array}{l}31(20 \%) \\
88(17 \%)\end{array}$ & $\begin{array}{l}128(80 \%) \\
443(83 \%)\end{array}$ & 0.392 & 1.22 & $0.774-1.920$ & & & \\
\hline $\begin{array}{l}\text { Health technician } \\
\text { Yes } \\
\text { No }\end{array}$ & $\begin{array}{c}14(15 \%) \\
105(18 \%)\end{array}$ & $\begin{array}{c}80(85 \%) \\
491(82 \%)\end{array}$ & 0.373 & 0.82 & $0.447-1.500$ & & & \\
\hline $\begin{array}{l}\text { Caregivers } \\
\text { Yes } \\
\text { No }\end{array}$ & $\begin{array}{c}3(17 \%) \\
116(17 \%)\end{array}$ & $\begin{array}{c}15(83 \%) \\
556(83 \%)\end{array}$ & 0.947 & 1.043 & $0.297-3.662$ & & & \\
\hline $\begin{array}{l}\text { Others } \\
\text { Yes } \\
\text { No }\end{array}$ & $\begin{array}{l}52(21 \%) \\
67(15 \%)\end{array}$ & $\begin{array}{l}196(79 \%) \\
378(85 \%)\end{array}$ & $0.053^{*}$ & 1.49 & $0.451-1.006$ & & & \\
\hline $\begin{array}{l}\text { Exposure to COVID-19 } \\
\text { case }(n=490)\end{array}$ & & & 0.020 & 2.28 & $1.141-4.543$ & & & \\
\hline Outside the hospital & $13(27 \%)$ & $35(73 \%)$ & & & & & & \\
\hline Inside the hospital & $62(14 \%)$ & $380(86 \%)$ & & & & & & \\
\hline $\begin{array}{l}\text { Exposure to COVID } 19 \\
\text { case inside the hospital } \\
(n=442)\end{array}$ & & & 0.095 & 1.59 & $0.923-2.749$ & & & \\
\hline Exposure to a patient & $27(18 \%)$ & $124(82 \%)$ & & & & & & \\
\hline Social contact & $35(12 \%)$ & $256(88 \%)$ & & & & & & \\
\hline
\end{tabular}

${ }^{*}$ Healthcare workers ${ }^{* *}$ Odds ratio $\quad{ }^{* * *}$ Confidence interval

interval [CI] 1.141-4.543). Inside the hospital, social contact with colleagues was (66\%) more common than exposure to a patient (34\%). For exposures inside the hospital, the risk of COVID-19 development was 1.6 times higher after exposure to a patient than the risk after exposure through social contact with a colleague; however, the difference was not statistically significant ( $P=0.095$; 95\% CI 0.923-2.749; (Table 2).
Furthermore, 15 of 27 cases were associated with exposure to two patients with severe COVID-19. One of these patients was in the emergency room and had received cardiopulmonary resuscitation; within 11 days, three doctors, three nurses, and two caregivers had positive PCR test results for SARS-CoV-2 despite the proper use of personal protective equipment (PPE). The second patient received care for four 


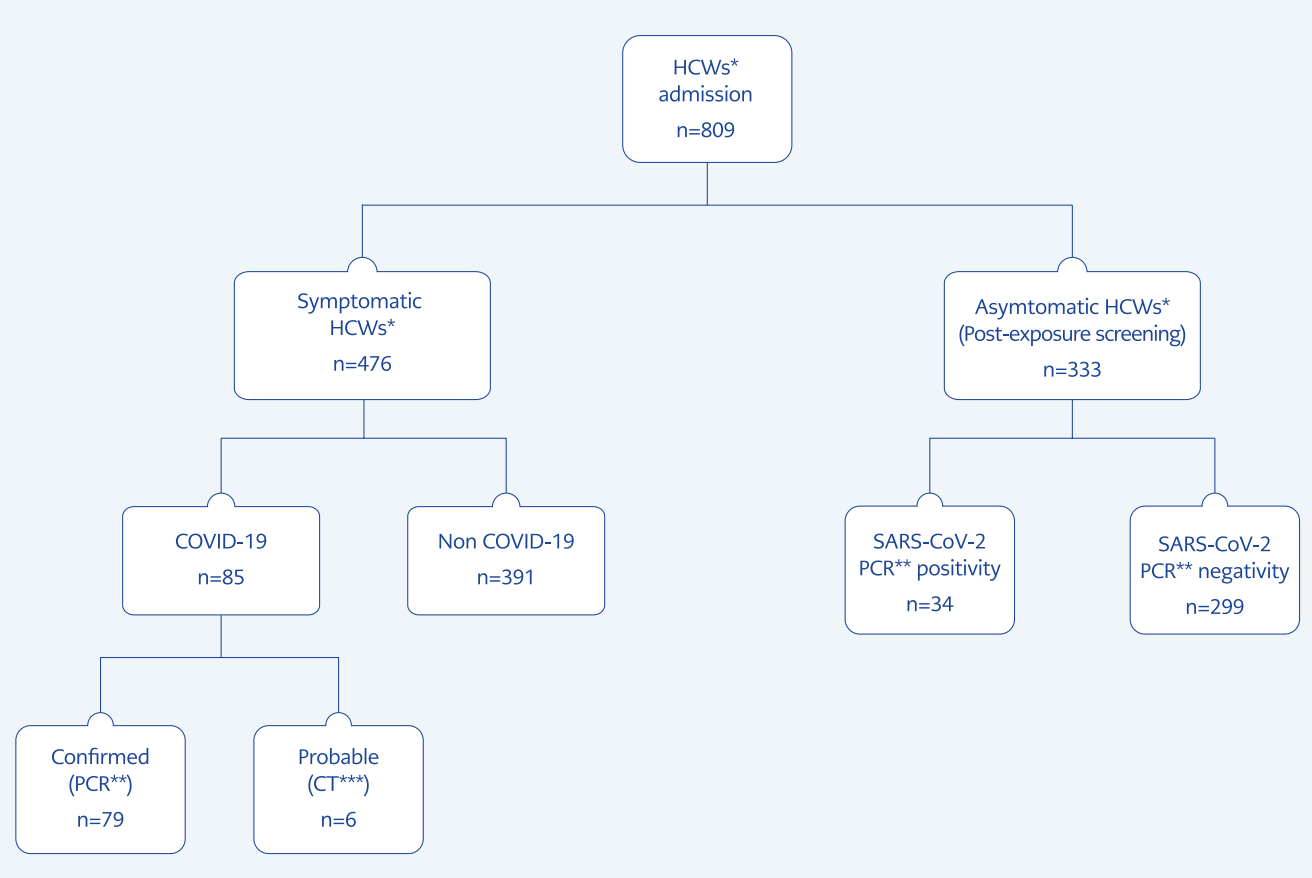

Figure 2. Admission of healthcare workers with or without typical symptoms for COVID-19.

days in two different departments before COVID-19 was diagnosed; within 14 days, three doctors, four nurses, one caregiver, and one housekeeper became infected from this patient and they have been used PPE properly. The exposure status of the HCWs on admission is shown in Figure 3.

The distribution of occupations for suspected exposure rates of admissions was 31\% doctors, 25\% nurses, $12 \%$ health technicians, $2 \%$ caregivers, and $30 \%$ other HCWs, who did not have direct contact with patients. Doctors and nurses were more likely than other HCWs to be exposed to COVID-19 patients inside the hospital $(P=0.001$ and $P=0.001$, respectively), while others were exposed via a family member or through social contact via other relatives or friends $(P=0.001)$. For doctors, infection development after exposure was statistically lower ( $P=0.001 ; 95 \%$ CI 0.128-0.547), whereas, for nurses, it was 1.5 times higher.

Inexperienced HCWs (<10years of experience) had 1.3 times more exposure than experienced HCWs. Remarkably, the former was exposed to COVID-19 patients inside hospital 1.7 times more often than experienced HCWs ( $\mathrm{P}=0.001 ; 95 \%$ CI 1.142-2.565). However, there were no differences in exposure rates between inexperienced and experienced HCWs through social contact. However, the rate of COVID-19 development was 1.5 times higher in experienced HCWs than in inexperienced HCWs $(P=0.20 ; 95 \%$ CI $0.938-2.517)$.

Among 809 admissions to the outpatient clinic, 476 patients (59\%) had typical COVID-19 symptoms. The most common symptoms were cough $(37 \%)$, sore throat (37\%), and fever (33\%). The rate of COVID-19 diagnosis was significantly higher in patients with loss of taste or smell (44\%), myalgia (26\%), fever $(25 \%)$, cough $(20 \%)$, and sore throat $(19 \%)$ at admission $(\mathrm{P}<0.05)$. In multivariate analysis, loss of taste or smell, myalgia, and fever were detected as the predictors of COVID-19. However, diarrhea seemed to be an exclusion criterion for COVID-19. (Table 3). The PCR test for SARS-CoV-2 was positive in $10 \%$ of asymptomatic HCWs. The most common symptoms in HCWs diagnosed with COVID-19 were fever (33\%), cough (30\%), and sore throat (29\%). Diarrhea (2\%) and shortness of breath (1\%) were less common symptoms. 
Table 3. Co-morbid diseases.

\begin{tabular}{|c|c|c|c|c|c|c|c|c|}
\hline \multirow{2}{*}{ Symptoms } & \multirow{2}{*}{$\begin{array}{c}\text { COVID-19 HCWs* } \\
\mathrm{N}(\%)\end{array}$} & \multirow{2}{*}{$\begin{array}{c}\begin{array}{c}\text { Non-infected } \\
\text { HCWs* }^{*}\end{array} \\
\mathrm{~N}(\%)\end{array}$} & \multicolumn{3}{|c|}{ Univariate analysis } & \multicolumn{3}{|c|}{ Multivariate analysis } \\
\hline & & & $\mathrm{p}$ & $\mathrm{OR}^{\star *}$ & $95 \% \mathrm{Cl}^{\star * *}$ & $\mathbf{P}$ & $\mathrm{OR}^{\star *}$ & $95 \% \mathrm{Cl}^{\star \star \star}$ \\
\hline Fever & & & 0.0001 & 2.41 & $\begin{array}{l}1.567- \\
3.714\end{array}$ & 0.002 & 2.06 & $\begin{array}{l}1.251- \\
3.140\end{array}$ \\
\hline $\begin{array}{l}\text { Yes } \\
\text { No }\end{array}$ & $\begin{array}{l}39(25) \\
80(12)\end{array}$ & $\begin{array}{l}116(75) \\
574(88)\end{array}$ & & & & & & \\
\hline Cough & & & 0.036 & 1.59 & $\begin{array}{l}1.031- \\
2.463\end{array}$ & 0.428 & 1.21 & $\begin{array}{c}0.758- \\
1.926\end{array}$ \\
\hline $\begin{array}{l}\text { Yes } \\
\text { No }\end{array}$ & $\begin{array}{l}35(20) \\
84(13)\end{array}$ & $\begin{array}{l}143(80) \\
547(87)\end{array}$ & & & & & & \\
\hline Sore throat & & & 0.048 & 1.557 & $\begin{array}{l}1.004- \\
2.415\end{array}$ & 0.283 & 1.29 & $\begin{array}{l}0.811- \\
2.052\end{array}$ \\
\hline $\begin{array}{l}\text { Yes } \\
\text { No }\end{array}$ & $\begin{array}{l}34(19) \\
85(13)\end{array}$ & $\begin{array}{l}141(81) \\
549(87)\end{array}$ & & & & & & \\
\hline Myalgia & & & 0.0001 & 2.36 & $\begin{array}{l}1.436- \\
3.888\end{array}$ & 0.010 & 2.02 & $\begin{array}{l}1.186- \\
3.457\end{array}$ \\
\hline $\begin{array}{l}\text { Yes } \\
\text { No }\end{array}$ & $\begin{array}{l}26(26) \\
93(13)\end{array}$ & $\begin{array}{c}73(74) \\
617(87)\end{array}$ & & & & & & \\
\hline New loss of taste/ smell & & & 0.0001 & 4.78 & $\begin{array}{l}2.044- \\
11.165\end{array}$ & 0.002 & 3.95 & $\begin{array}{l}1.651- \\
9.469\end{array}$ \\
\hline $\begin{array}{l}\text { Yes } \\
\text { No }\end{array}$ & $\begin{array}{c}10(45) \\
109(14)\end{array}$ & $\begin{array}{c}13(55) \\
677(86)\end{array}$ & & & & & & \\
\hline Diarrhea & & & 0.013 & 0.164 & $\begin{array}{l}0.040- \\
0.681\end{array}$ & 0.012 & 0.161 & $\begin{array}{l}0.038- \\
0.673\end{array}$ \\
\hline $\begin{array}{l}\text { Yes } \\
\text { No }\end{array}$ & $\begin{array}{c}2(3) \\
117(16)\end{array}$ & $\begin{array}{l}65(97) \\
625(84)\end{array}$ & & & & & & \\
\hline Dyspnea & & & 0.172 & 0.246 & $\begin{array}{l}0.033- \\
1.837\end{array}$ & & & \\
\hline $\begin{array}{l}\text { Yes } \\
\text { No }\end{array}$ & $\begin{array}{c}1(4) \\
118(15)\end{array}$ & $\begin{array}{c}23(96) \\
667(85)\end{array}$ & & & & & & \\
\hline Asymptomatic & & & 0.003 & 0.523 & $\begin{array}{l}0.342- \\
0.880\end{array}$ & & & \\
\hline $\begin{array}{l}\text { Yes } \\
\text { No }\end{array}$ & $\begin{array}{l}34(10) \\
85(18)\end{array}$ & $\begin{array}{l}299(90) \\
391(82)\end{array}$ & & & & & & \\
\hline
\end{tabular}

*Healthcare workers ${ }^{* *}$ Odds ratio $\quad{ }^{* * *}$ Confidence interval

Factors such as male gender, being a doctor, and exposure to COVID-19 cases were significantly different between the group diagnosed with COVID-19 and the group not diagnosed with COVID-19 ( $P=0.012, P=0.014$ and $P=0,020$, respectively). However, there were no differences with regard to years of experience $(P>0.05)$. In addition, multivariate analysis revealed that male gender and occupation categories besides doctors were independent risk factors for the development of COVID-19 in HCWs ( $P<0.01$; OR 1.72; 95\% CI 1.1492.576 and $P<0.01$; OR 0.47; 95\% CI 0.277-0.804).

\section{DISCUSSION}

We described the COVID-19, and its predictors among the HCWs admitted to the outpatient clinic with the suspect of infection. Seventeen percent of HCWs diagnosed with COVID-19 were admitted to the COVID-19 outpatient clinic, and they accounted for $16 \%$ of the total COVID-19 cases in our center. Although there are no published reports from Turkey, the Republic of Turkey Ministry of Health announced that $>120,000 \mathrm{HCW}$ PCR test results 


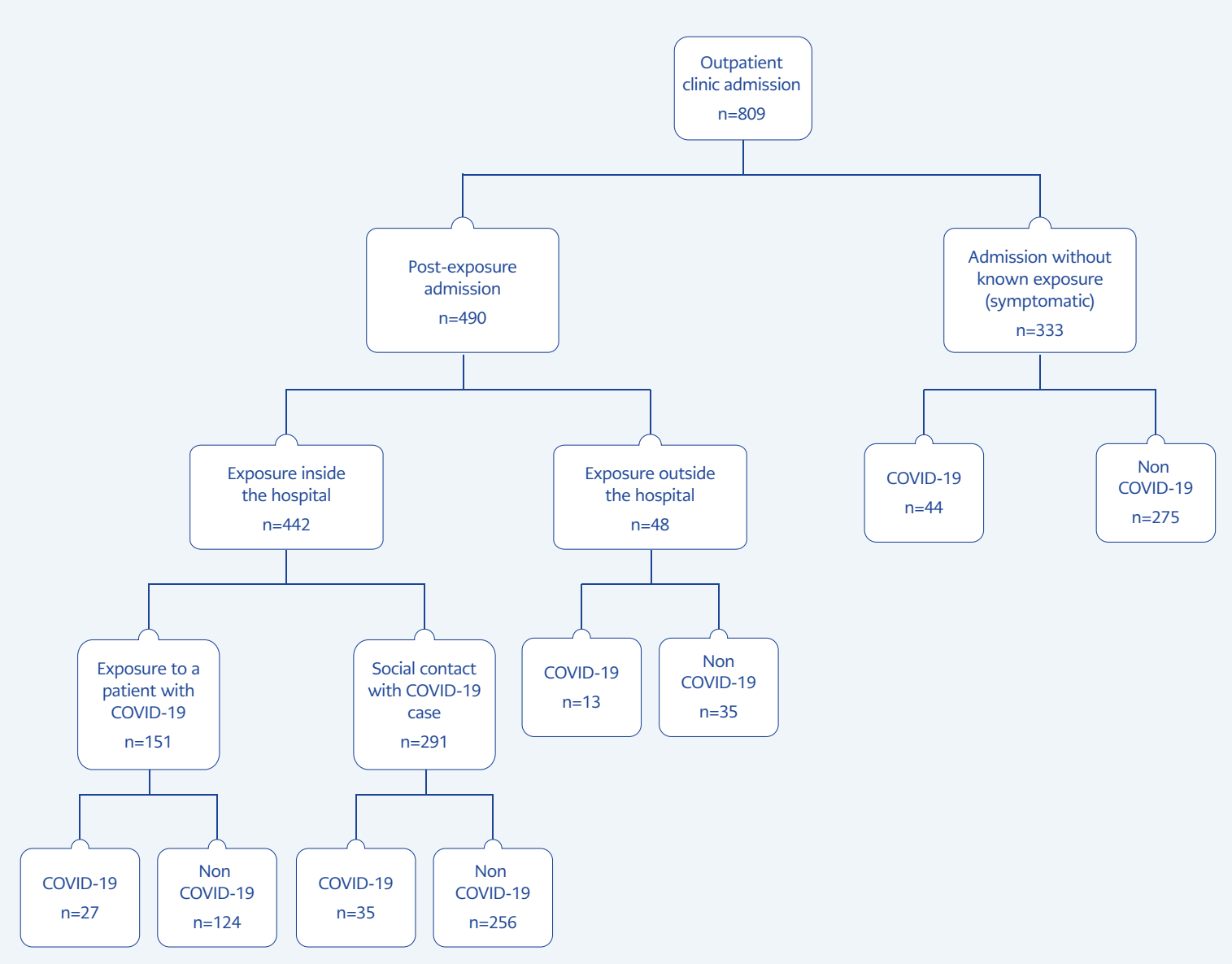

Figure 3. Exposure status of HCWs on admission.

were positive for SARS-CoV-2 at the beginning of December 2020 [(8)]. According to the WHO's report in September 2020, nearly 14\% of COVID-19 cases globally were among HCWs, and this proportion may be as high as $35 \%$ in some countries $(3,9)$.

Admissions of female HCWs were more common in our study; however, unlike previous studies, COVID-19 diagnosis was higher in males than in female individuals (10-13). Nurses were the most infected group among different occupation categories, similar to previous study results (10, 13). Although admissions after suspected exposure were higher in doctors, infection rates were lower. Higher infection rates in nurses may result from longer duration and higher exposure rates to the patients. Furthermore, doctors may be assumed to have better education about COVID-19, resulting in appropriate attitudes and behaviors for protection both inside and outside the hospital (14).

Like recent studies, the most common symptoms among admitted patients were respiratory symptoms (13). However, loss of taste or smell, myalgia, and fever were predictors of COVID-19, and nearly half of the patients with these symptoms were diagnosed. Sudden loss of taste or smell is an important symptom for diagnosing COVID-19 in the early stage, especially in mild-to-moderate cases $(15,16)$. Therefore, it was recommended that during the COVID-19 outbreak, HCWs with a sudden loss of smell should isolate at home, practice social distancing, and undergo a SARS-CoV-2 diagnostic test as soon as possible (17). HCWs with diarrhea were mostly found to be SARS-CoV-2 negative. Although detailed analysis for causative agents was 
not performed, we postulate that other viral and bacterial diarrhea were expected to be common during our study period because of the seasonal properties of diseases $(18,19)$. Although most cases were mild, the hospitalization rate reported in this study was higher than that reported in other studies, likely because of the governmental approach for hospitalization indications (isolation to limit dissemination) at the beginning of the pandemic $(10,13)$. However, unlike other studies, there were no ICU admissions and deaths $(10,20)$.

Asymptomatic infection is another important source of SARS-CoV-2 transmission in healthcare facilities. We found positive SARS-CoV-2 PCR test result in 10\% of asymptomatic HCWs. Numerous studies highlight the importance of screening and early detection in limiting the spread of the disease $(21,22)$.

Our main study finding was that the most important risk factor for SARS-CoV-2 infection in HCWs in the early phase of the outbreak was suspected exposure to COVID-19 cases outside the hospital, similar to other studies $(23,24)$. Among HCWs admitted to the COVID-19 outpatient clinic, 61\% had suspected exposure inside or outside the hospital, of whom $16 \%$ got infected with COVID-19, which is a higher percentage than those reported in other studies (25). The highest test positivity rate was detected after social or familial contact outside the hospital. This could be related to HCWs ignoring social distancing guidelines and personal protection protocols in social or household settings outside of patient care areas (25). A study from Singapore reported that in the initial SARS-CoV-2 outbreak phase, community transmission, rather than healthcare-associated transmission, predominated (26).

While most studies reported that the risk of transmission inside the hospital is higher in breakrooms, nursing stations, and other social areas, our study showed that the risk of COVID-19 development was higher after exposure to a patient rather than after social contact. Most HCWs infected after patient exposure were associated with two index cases. These two clusters constituted 55\% of the total cases of patient exposure. Adam et al. reported that $19 \%$ of SARS-CoV-2 infections in Hong
Kong were responsible for $80 \%$ of all transmissions, highlighting the significance of superspreading events in the COVID-19 pandemic (27). Yuki et al. analyzed 61 clusters among various communities in Japan and found that 30\% were related to healthcare facilities (28). Many studies have reported SARS and the Middle East respiratory syndrome coronavirus outbreak clusters $(26,29)$.

In our study, only a quarter of the infected HCWs were working in departments where COVID-19 patients are primarily. These data emphasized that all HCWs, not only working in departments where COVID-19 patients are primarily followed, are at risk of SARS-CoV-2 exposure. Therefore, training on complying with infection control measures and the appropriate use of PPE for all HCWs is crucial. Many studies have reported that the transmission rate of SARS-CoV-2 is higher in areas not considered high risk for COVID-19 $(13,14,25)$. Work experience is another factor in the exposure rate. In our study, exposure to a COVID-19 case inside the hospital was higher among inexperienced HCWs ( $<10$ years of work experience); however, the development of infection was 1.7 times higher in the more experienced group. Zhang et al. reported that frequent participation in training on COVID-19 and PPE use negatively correlates with years of experience and frontline status (14).

Our study was limited in that we did not question the participants about their underlying medical conditions. We also could not compare our data with local data because there have not been many studies from Turkey.

In conclusion, HCWs are at higher risks of COVID-19 than other members of the community because of the exposure rate. Ideally, after suspected exposure to a COVID-19 case, HCWs should be screened for SARS-CoV-2 and monitored closely for symptom development. These risks can be minimized by continuous training, strict infection control protocols, and appropriate PPE use both inside the hospital and in social or household settings. 
Ethical Approval: The Institutional Review Board of Başkent University, School of Medicine approved the study with the decision number of KA20/367 (October 6, 2020).

Informed Consent: This is a retrospective study for which no formal consent is required.

Peer-review: Externally peer-reviewed

Author Contributions: Concept - Ö.A., H.A.; Design - Ö.A., Ç.E.; Supervision - Ö.A., H.A; Data Collection and/or Processing - Ç.E., N.S., T.Y.Y., N.S.; Analysis and/or Interpretation - Ç.E., Ö.A., N.S., T.Y.Y.; Literature Review - Ç.E., Ö.A., N.S., T.Y.Y; Writer - Ç.E.; Critical Reviews - Ö.A., H.A.
Conflict of Interest: The authors have no conflict of interest to declare.

Financial Disclosure: The authors declared that this study has received no financial support.

Acknowledgements: We would like to thank Editage [https:// editage.com/] for editing and reviewing this manuscript for English language.

Scientific presentations: Preliminary results were accepted as an e-poster at the 31st ECCMID (European Congress of Clinical Microbiology and Infectious Diseases/ July 9-12, 2021).

\section{REFERENCES}

1 Transmission of SARS-CoV-2: implications for infection prevention precautions. [Internet]. World Health Organization. (July 9, 2020; cited August 8, 2021). Available from: https://www.who.int/newsroom/commentaries/detail/transmission-of-sars-cov-2-implications-for-infection-prevention-precautions

2 Branch-Elliman W, Savor Price C, McGeer A, Perl TM. Protecting the frontline: designing an infection prevention platform for preventing emerging respiratory viral illnesses in healthcare personnel. Infect Control Hosp Epidemiol. Mar, 2015;36(3):33645. [CrossRef]

3 Keep health workers safe to keep patients safe [Internet]. World Health Organization. (September 17, 2020; cited August 8, 2021). Available from: https://www.who.int/news/item/1709-2020-keep-health-workers-safe-to-keep-patients-safe-who.

4 Sim MR. The COVID-19 pandemic: major risks to healthcare and other workers on the front line. Occup Environ Med. May, 2020;77(5):281-2. [CrossRef]

5 WHO COVID-19 Case definition [Internet]. World Health Organization. (December 16, 2020; cited August 8, 2021). Available from: https://www.who.int/publications/i/item/WHO-2019nCoV-Surveillance_Case_Definition-2020.1

6 Symptoms of COVID-19 [Internet]. Centers for Disease Control and Prevention. (updated February 22, 2021; cited August 8, 2021). Available from: https://www.cdc.gov/coronavirus/2019-ncov/symptoms-testing/symptoms.html

7 COVID-19 bilgilendirme platformu: Temaslı takibi, salgın yönetimi, evde hasta izlemi ve filyasyon [Internet]. T.C. Sağllk Bakanlığı. (updated May 29, 2021; cited August 8, 2021). Turkish. Available from: https://covid19.saglik.gov.tr/TR-66339/temasli-takibi-salgin-yonetimi-evde-hasta-izlemi-ve-filyasyon.html

8 Sağlık Bakanı rakamları açıkladı: COVID-19 salgınına yakalanan sağlık çalışanı sayısı 120 bini geçti [Internet]. Medimagazin. (December 10, 2020; cited August 8, 2021). Turkish. Available from: https://www.medimagazin.com.tr/medilife//tr-saglikbakani-rakamlari-acikladi-covId-19-salginina-yakalanan-saglik-calisani-sayisi-120-bini-gecti-10-686-92796.html.
9 Chou R, Dana T, Buckley DI, Selph S, Fu R, Totten AM. Epidemiology of and risk factors for coronavirus infection in health care workers: A living rapid $r$ Ann Intern Med. Jul 21, 2020;173(2):120-36. [CrossRef]

10 Guerrero-Torres L, Caro-Vega Y, Crabtree-Ramírez B, Sierra-Madero JG. Clinical characteristics and mortality of healthcare workers with severe acute respiratory syndrome coronavirus 2 (SARS-CoV-2) infection in Mexico City. Clin Infect Dis. Jul 1, 2021;73(1):e199-e205. [CrossRef]

11 Çelebi G, Pişkin N, Çelik-Bekleviç A, Altunay Y, Salcı-Keleş A, Tüz MA, et al. Specific risk factors for SARS-CoV-2 transmission among health care workers in a university hospital. Am J Infect Control. Oct, 2020;48(10):1225-30. [CrossRef]

12 Madran B, Keske Ş, Beşli Y, Bozkurt İ, Ergönül Ö. The risk of SARS-CoV-2 infection among healthcare workers. Infect Dis Clin Microbiol. 2020;2:54-60. [CrossRef]

13 Vandercam G, Simon A, Scohy A, Belkhir L, Kabamba B, Rodriguez-Villalobos $\mathrm{H}$, et al. Clinical characteristics and humoral immune response in healthcare workers with COVID-19 in a teaching hospital in Belgium. J Hosp Infect. Dec, 2020;106(4):713-20. [CrossRef]

14 Zhang M, Zhou M, Tang F, Wang Y, Nie H, Zhang L, et al. Knowledge, attitude, and practice regarding COVID-19 among healthcare workers in Henan, China. J Hosp Infect. Jun, 2020;105(2):183-7. [CrossRef]

15 Lee Y, Min P, Lee S, Kim SW. Prevalence and duration of acute loss of smell or taste in COVID-19 p J Korean Med Sci. May 11, 2020;35(18):e174. [CrossRef]

16 Gautier JF, Ravussin Y. A new symptom of COVID-19: Loss of taste and smell. Obesity (Silver Spring). May, 2020;28(5):848. [CrossRef]

17 Mullol J, Alobid I, Mariño-Sánchez F, Izquierdo-Domínguez A, Marin C, Klimek L, et al. The loss of smell and taste in the COVID-19 outbreak: A tale of many c Curr Allergy Asthma Rep. Aug 3, 2020;20(10):61. [CrossRef] 
18 Chao DL, Roose A, Roh M, Kotloff KL, Proctor JL. The seasonality of diarrheal pathogens: A retrospective study of seven sites over three years. PLoS Negl Trop Dis. Aug 15, 2019;13(8):e0007211. [CrossRef]

19 Gong X-H, Wu H-Y, Li J, Xiao W-J, Zhang X, Chen M, et al. Epidemiology, aetiology and seasonality of infectious diarrhoea in adult outpatients through active surveillance in Shanghai China, 2012-2016: A cross-sectional study. BMJ Open. Sep 4, 2018;8(9):e019699. [CrossRef]

20 Harrison D, Muradali K, El Sahly H, Bozkurt B, Jneid H. Impact of the SARS-CoV-2 pandemic on health-care workers. Hosp Pract (1995). Oct, 2020;48(4):161-4. [CrossRef]

21 Baker MA, Rhee C, Fiumara K, Bennett-Rizzo C, Tucker R, Wil liams SA, et al. COVID-19 infections among HCWs exposed to a patient with a delayed diagnosis of COVID-19. Infect Control and Hosp Epidemiol. 2020;41(9):1075-6. [CrossRef]

22 Rivett L, Sridhar S, Sparkes D, Routledge M, Jones NK, Forrest S, et al. Screening of healthcare workers for SARS-CoV-2 highlights the role of asymptomatic carriage in COVID-19 transmission. Elife. May 11, 2020;9:e58728. [CrossRef]

23 Pınarlık F, Genç Z, Kapmaz M, Tekin S, Ergönül Ö. Risk groups for SARS-CoV-2 infection among healthcare workers: Community versus hospital transmission. I Dis. Rep.2021:13(3),7249. CrossRef

24 Kayı İ, Madran B, Keske Ş, Karanfil Ö, Arribas JR, Pshenichnaya $\mathrm{N}$, et al. The seroprevalence of SARS-CoV-2 antibodies among health care workers before the era of vaccination: A systematic review and meta-analysis. Clin Microbiol Infect. Jun 8, 2021 [Epub ahead of print] [CrossRef]
25 Fell A, Beaudoin A, D'Heilly P, et al. SARS-CoV-2 exposure and infection among health care personnel [Internet]. MMWR Morb Mortal Wkly Rep 2020;69:1605-10. Available from: https://www.cdc.gov/mmwr/volumes/69/wr/mm6943a5. htm?s_cid=mm6943a5_w

26 Wee LE, Sim XYJ, Conceicao EP, Aung MK, Goh JQ, Yeo DWT, et al. Containment of COVID-19 cases among healthcare workers: The role of surveillance, early detection, and outbreak management. Infect Control Hosp Epidemiol. Jul, 2020;41(7):76571. [CrossRef]

27 Adam DC, Wu P, Wong JY,Lau EHY, Tsang TK, Cauchemez S, et al. Clustering and superspreading potential of SARS-CoV-2 infections in Hong Kong. Nat Med. 2020;26,1714-9. [CrossRef]

28 Furuse Y, Sando E, Tsuchiya N, Miyahara R, Yasuda I, Ko YK, et al. Clusters of coronavirus disease in communities, Japan, January-April, 2020. Emerging Infectious Diseases. 2020;26(9):2176-9. [CrossRef

29 Cho SY, Kang JM, Ha YE, Park GE, Lee JY, Ko JH, et al. MERS-CoV outbreak following a single patient exposure in an emergency room in South Korea: An epidemiological outbreak study. Lancet. Sep 3, 2016;388(10048):994-1001. [CrossRef] 